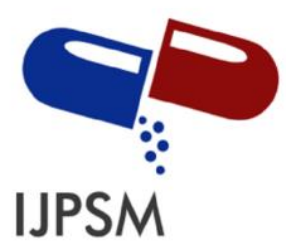

Saxena Kiran et al, International Journal of Pharmaceutical Sciences and Medicine (IJPSM),

Vol.7 Issue. 1, January- 2022, pg. 81-93

ISSN: 2519-9889

Impact Factor: 5.721

\title{
Formulation and Evaluation of Effervescent Floating Tablet of Levofloxacin by Using Limonia acidissima and Xanthan as Natural Gum
}

\author{
Saxena Kiran; Pawar Rajat; Patidar Sunita \\ Swami Vivekanand College of Pharmacy, Indore \\ DOI: 10.47760/ijpsm.2022.v07i01.004
}

\begin{abstract}
The main objective of the study is the formulation and evaluation of effervescent floating tablet of levofloxacin by using limonia acidissima and xanthan as natural gum. The preformulation study of levofloxacin was conducted and $\lambda$ max was found at $288 \mathrm{~nm}$. The Effervescent Floating tablets containing levofloxacin were prepared by direct compression technique using Limonia acidissima and xanthan gum combination and varying concentrations of different ratio of polymers with Sodium bicarbonate and citric acid. All the ingredients were accurately weighed and passed through different mesh sieve no. 40. Drug, Polymer and other excipients (except talc and magnesium streate) were mixed thoroughly, passed thoroughly, passed through sieved number 40. Then, except Magnesium stearate all other ingredients were blended uniformly in glass mortar. Various formulations of effervescent floating tablet of levofloxacin $F 1, F 2, F 3, F 4, F 5, F 6, F 7$ and $F 8$ was prepared. The prepared granules was evaluated for different parameters like Bulk density, Tapped density, Angle of repose, Carr's index, Hausner's ratio, which shows the excellent flow properties of formulation. The physical characteristic of levofloxacin effervescent floating tablets (F1 to F8) such as thickness, diameter, hardness, friability, weight variation and drug content were determined and results of the formulations (F1 to F8) found to be within the limits specified in official books. The drug content of all the formulation were found to be in the range of 95.2 to 99.2. Effervescent floating tablet of different formulations were noted. With reference to buoyancy studies results it can be concluded that the batch containing limonia acidissima showed good buoyancy lag time (BLT) and total floating time (TFT). Formulation F1 and F8 containing xanthan gum showed good BLT of 28 and 78 sec and TFT of more than $12 \mathrm{hrs}$. The drug released from formulation F1 to F4 was found to be 93.2, 93.3, 94.2 and $90.1 \%$ for levofloxacin respectively. The drug released from formulation $\mathrm{F5}$ to $\mathrm{F} 8$ was found to be 89.3, 88.1, 90.1 and $95.1 \%$ for levofloxacin respectively. These results are indicating that has higher drug retarding ability for long duration.

Keywords: Effervescent floating tablet, levofloxacin, limonia acidissima, Xanthan Gum, buoyancy lag time, Total floating time, In-Vitro drug released.
\end{abstract}




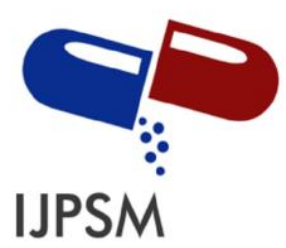

Saxena Kiran et al, International Journal of Pharmaceutical Sciences and Medicine (IJPSM), Vol.7 Issue. 1, January- 2022, pg. 81-93

ISSN: 2519-9889

Impact Factor: 5.721

\section{INTRODUCTION}

Levofloxacin is a broad-spectrum, third-generation fluoroquinolone antibiotic and optically active Lisomer of ofloxacin with antibacterial activity. Levofloxacin diffuses through the bacterial cell wall and acts by inhibiting DNA gyrase (bacterial topoisomerase II), an enzyme required for DNA replication, RNA transcription, and repair of bacterial DNA. Inhibition of DNA gyrase activity leads to blockage of bacterial cell growth.

One of the purpose of these formulations was to maintain in vitro buoyancy as well as in vivo duration of floating stable for at least 24/12 hours. Floating drug delivery systems, with an aim of improved patient compliance, better therapeutic efficacy, less side effects and reduced dosage regimen with less toxicity for treatment for many acute and chronic diseases.

Hence, in the present work, an attempt is made to develop effervescent floating tablets of levofloxcin, with the use of Limonia acidissima and xanthan as natural gum for their floating effect. Direct compression technique is used for tablet formulation along with the addition of suitable additives by using of sodium bicarbonate, citric acid, magnesium stearate, lactose and talc.

\section{MATERIALS AND METHOD}

\section{MATERIALS}

Levofloxacin was received as a gift sample from Gift sample from Cypco Company ,Rau, Indore (M.P). Limonia acidissima was purchased from local market. Sodium bicarbonate , Citric acid, Microcrystalline cellulose(MCC), Magnesium stearate and talc from SD- Fine Chemicals. All other solvent and reagent are used was of analytical grade.

\section{EXPERIEMENTALS}

\subsection{Identification of Drug}

\subsubsection{By UV Spectroscopy}

Identification of the drug, levofloxacin was done by UV Spectrophotometric method using Shimadzu Spectrophotometer UV-1800 (Shimadzu Corp. Japan). $100 \mathrm{mg}$ of levofloxacin was accurately weighed and transferred to a $100 \mathrm{ml}$ volumetric flask. It was dissolved in sufficient amount of $0.1 \mathrm{~N}$ $\mathrm{NaOH}$ and volume was made upto $100 \mathrm{ml}$ with $0.1 \mathrm{~N} \mathrm{NaOH}$. Exactly $10 \mathrm{ml}$ of the stock solution was pipetted out and was diluted to $100 \mathrm{ml}$ with $0.1 \mathrm{~N} \mathrm{NaOH}(10 \mu \mathrm{g} / \mathrm{ml})$. The spectrum was recorded in the range of 200-400 nm. Spectrum was recorded. The $\lambda$ max of levofloxacin was obtained at $288 \mathrm{~nm}$. The UV spectrum of levofloxacin drug is shown in the fig. 1. 


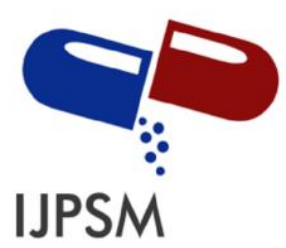

Saxena Kiran et al, International Journal of Pharmaceutical Sciences and Medicine (IJPSM), Vol.7 Issue. 1, January- 2022, pg. 81-93

ISSN: 2519-9889

Impact Factor: 5.721

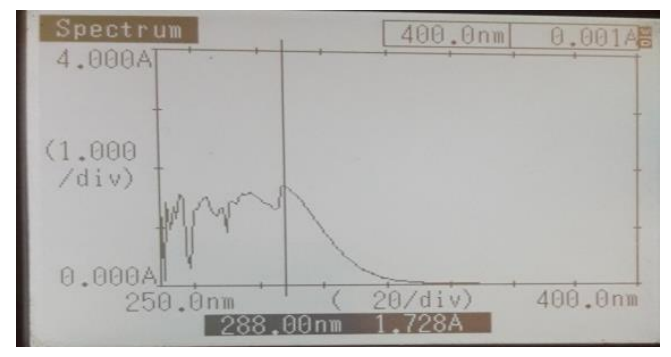

Figure 1: Spectrum of levofloxacin by UV Spectroscopy

\subsubsection{By melting point determination}

The melting point of drug sample was determined by using melting point apparatus. The melting point was found to be in the range of $226-228^{\circ} \mathrm{C}$, which is found to be similar as given in the reference. The melting point of levofloxacin is shown in the table 2 .

Table 2: Melting Point of Levofloxacin

\begin{tabular}{|c|c|c|}
\hline Drug & Observed & Refrence \\
\hline Levofloxacin & $226-228^{\circ} \mathrm{C}$ & $225^{0}-227^{\circ} \mathrm{C}$ \\
\hline
\end{tabular}

\subsubsection{Preparation of standard Calibration curve of levofloxacin in $0.1 \mathrm{~N} \mathrm{NaOH}(\lambda \mathrm{max}$}

\section{$288 \mathrm{~nm})$}

Calibration curve of levofloxacin was prepared in $0.1 \mathrm{NaOH}$ at $288 \mathrm{~nm}$. The absorbance values (mean of three determinations) with their standard deviation at different concentration in the range of 2-12 $\mu \mathrm{g} / \mathrm{ml}$ for $0.1 \mathrm{~N} \mathrm{NaOH}$ are tabulated. The drug obeys Beer's Lambert law in the concentration range. Linear regression analysis for all calibration curves of levofloxacin is given in Table. So, this equation was used for the calculation of the solubility of the drug in different solvent, drug content and drug release. The calibration curve of levofloxacin is shown in fig 4. 


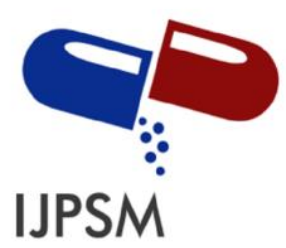

Saxena Kiran et al, International Journal of Pharmaceutical Sciences and Medicine (IJPSM),

Vol.7 Issue. 1, January- 2022, pg. 81-93

ISSN: 2519-9889

Impact Factor: 5.721

Table 3: Data of standard calibration curve of levofloxacin in $0.1 \mathrm{~N} \mathrm{NaOH}$

\begin{tabular}{|l|l|l|}
\hline S.No. & $\begin{array}{l}\text { Concentration } \\
(\boldsymbol{\mu g} / \mathbf{m l})\end{array}$ & $\begin{array}{l}\text { Absorbance } \\
(\mathbf{n m})\end{array}$ \\
\hline 1. & 0 & 0 \\
\hline 2. & 2 & 0.102 \\
\hline 3. & 4 & 0.187 \\
\hline 4. & 6 & 0.276 \\
\hline 5. & 8 & 0.361 \\
\hline 6. & 10 & 0.441 \\
\hline 7. & 12 & 0.515 \\
\hline
\end{tabular}

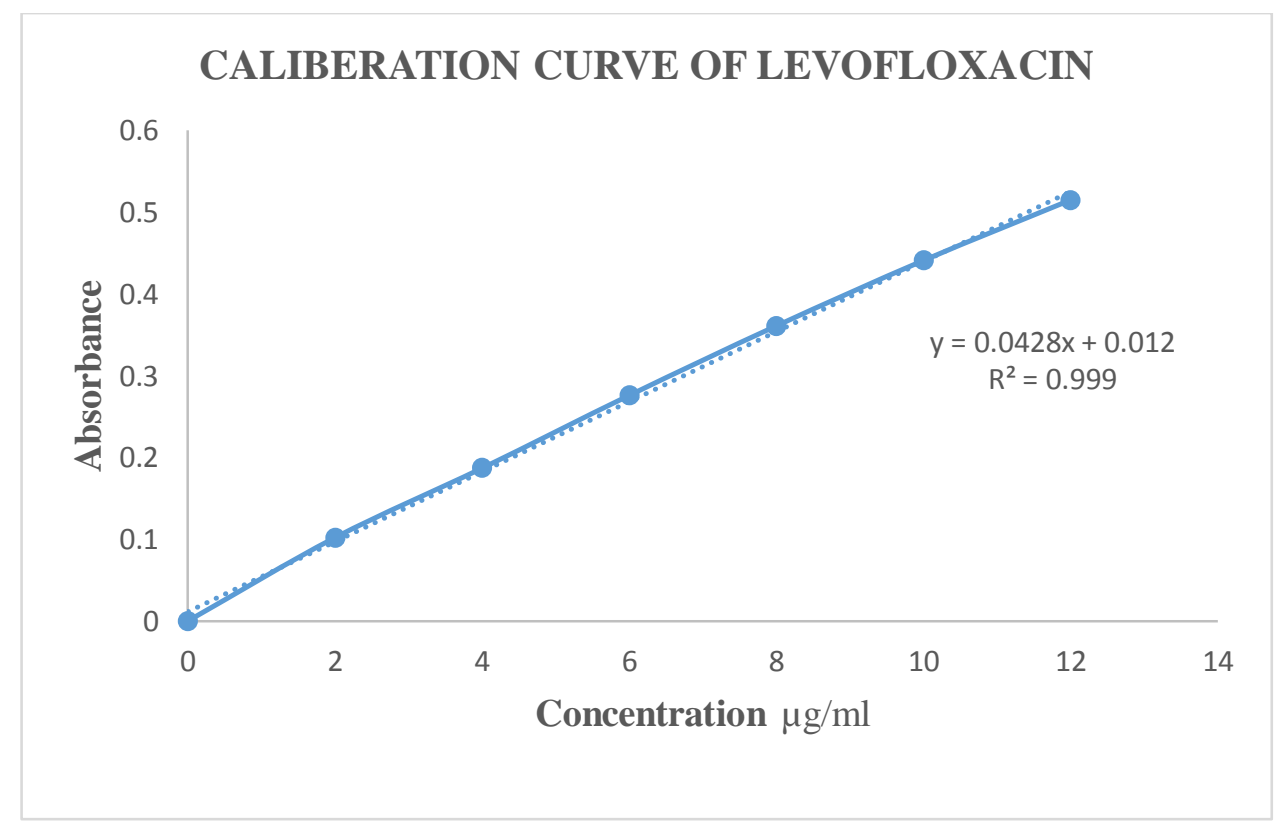

Fig 4: Calibration curve of levofloxacin in $0.1 \mathrm{~N} \mathrm{NaOH}$.

\subsection{Solubility studies of drug}

Quantitative solubility analysis of levofloxacin was determined in different solvents. The drug levofloxacin was found to be more soluble in ethanol, methanol, $\mathrm{Hcl}$ and $\mathrm{NaOH}$. This shows that drug 


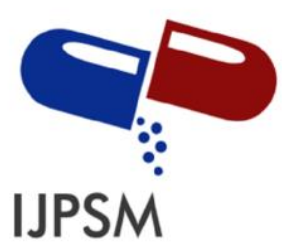

Saxena Kiran et al, International Journal of Pharmaceutical Sciences and Medicine (IJPSM),

Vol.7 Issue. 1, January- 2022, pg. 81-93

ISSN: 2519-9889

Impact Factor: 5.721

is more soluble only in organic solvents, which shows the lipophilic nature of the drug. The results are found to be similar as given in the reference. The results are disclosed in table 5.

Table 5 : Quantitative solubility analysis:

\begin{tabular}{|l|l|l|}
\hline S.no & Solvents & Solubility $\mathbf{~ m g / m l}$ \\
\hline 1. & Water & 52.3 \\
\hline 2. & Ethanol & 112 \\
\hline 3. & $\mathrm{NaOH}$ & 102.2 \\
\hline 4. & Hcl & 101.8 \\
\hline 5. & Methanol & 123 \\
\hline
\end{tabular}

\section{FORMULATION AND EVALUATION OF EFFERVESCENT FLOATING TABLET OF LEVOFLOXACIN}

\subsection{Formulation of effervescent floating tablet of levofloxacin by direct compression}

\section{method}

Formulation of effervescent floating tablet includes the selection of natural gum, polymer, gas generating agent, buffering agent, diluent, lubricant and glidant. The effervescent floating tablet was prepared using Limonia acidissima and xanthan as natural gum, Poly vinyl pyrrolidone K30 as polymer, Sodium bicarbonate as gas generating agent, Citric acid as buffering agent, Micro Crystalline Cellulose as Diluent, Magnesium stearate as Lubricant and Talc as Glidant. Several formulations was prepared by taking different drug concentration in natural gum and polymers with varying ratio of binder to lubricants. The formula is shown in the table 6 .

The Effervescent Floating tablets containing levofloxacin were prepared by direct compression technique using Limonia acidissima and xanthan gum combination and varying concentrations of different ratio of polymers with Sodium bicarbonate and citric acid. All the ingredients were accurately weighed and passed through different mesh sieve no. 40. Drug, Polymer and other excipients (except talc and magnesium streate) were mixed thoroughly, passed thoroughly, passed through sieved number 40. Then, except Magnesium stearate all other ingredients were blended uniformly in glass mortar. After sufficient mixing of drug as well as other components, Magnesium stearate was added, as post lubricant, and further mixed for additional 2-3 minutes. After Pre 


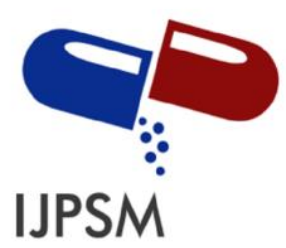

Saxena Kiran et al, International Journal of Pharmaceutical Sciences and Medicine (IJPSM), Vol.7 Issue. 1, January- 2022, pg. 81-93

ISSN: 2519-9889

Impact Factor: 5.721

compression characterization the tablets were compressed using rotary tablet machine. The weights of the tablets were kept constant for all formulation.

Table 6: composition of levofloxacin floating tablet

\begin{tabular}{|l|l|l|l|l|l|l|l|l|}
\hline Ingredients (Mg) & F1 & F2 & F3 & F4 & F5 & F6 & F7 & F8 \\
\hline levofloxacin & 250 & 250 & 250 & 250 & 250 & 250 & 250 & 250 \\
\hline Limonia acidissima & 10 & 20 & 30 & 40 & 50 & 60 & 70 & 80 \\
\hline Xanthan gum & 80 & 70 & 60 & 50 & 40 & 30 & 20 & 10 \\
\hline Microcrystalline cellulose & 15 & 15 & 15 & 15 & 15 & 15 & 15 & 15 \\
\hline Polyvinyl pyrolidine K30 & 15 & 15 & 15 & 15 & 15 & 15 & 15 & 15 \\
\hline Sodium bicarbonate & 50 & 50 & 50 & 50 & 50 & 50 & 50 & 50 \\
\hline Citric acid & 20 & 20 & 20 & 20 & 20 & 20 & 20 & 20 \\
\hline Magnesium stearate & 5 & 5 & 5 & 5 & 5 & 5 & 5 & 5 \\
\hline Talc & 5 & 5 & 5 & 5 & 5 & 5 & 5 & 5 \\
\hline Total & 450 & 450 & 450 & 450 & 450 & 450 & 450 & 450 \\
\hline
\end{tabular}

\subsection{Evaluation of Effervescent Floating Tablet of Levofloxacin:}

\subsubsection{Bulk Characterization of levofloxacin granules:}

The bulk density of various formulations were found to be between 30 to 35.3, tapped density between 0.261 to 0.619 , Hausner's ratio between 0.292 to 0.543 , Carr's index between 8.438 to 10.38 , which shows the good compressibility index of formulations. The angle of repose was found to be between 4.77 to 5.72, which shows the excellent flow properties of formulation. Results of measurements such as Tapped density, Angle of repose, Carr's index, Hausner's ratio are presented in the table 7 . 


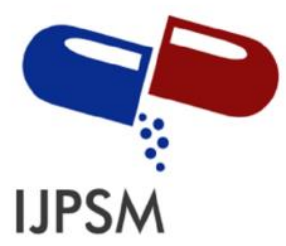

Saxena Kiran et al, International Journal of Pharmaceutical Sciences and Medicine (IJPSM), Vol.7 Issue. 1, January- 2022, pg. 81-93

ISSN: 2519-9889

Impact Factor: 5.721

Table 7 : Determination of flow properties of granules:

\begin{tabular}{|l|l|l|l|l|l|}
\hline Batch code & $\begin{array}{l}\text { Bulk } \\
\text { density }\left(\mathbf{g} / \mathbf{c m}^{\mathbf{3})}\right.\end{array}$ & $\begin{array}{l}\text { Tapped } \\
\text { density }\left(\mathbf{g} / \mathbf{c m}^{\mathbf{3}}\right)\end{array}$ & $\begin{array}{l}\text { Hausner's } \\
\text { ratio }\end{array}$ & $\begin{array}{l}\text { Carr's } \\
\text { ratio\% }\end{array}$ & $\begin{array}{l}\text { Angle of } \\
\text { repose }\end{array}$ \\
\hline F1 & 32.36 & 0.261 & 0.292 & 9.723 & 5.42 \\
\hline F2 & 35.4 & 0.521 & 0.352 & 8.438 & 4.77 \\
\hline F3 & 32.2 & 0.504 & 0.323 & 8.902 & 5.02 \\
\hline F4 & 28.9 & 0.545 & 0.442 & 10.38 & 5.72 \\
\hline F5 & 30.2 & 0.619 & 0.543 & 10.02 & 5.43 \\
\hline F6 & 29.7 & 0.546 & 0.378 & 9.423 & 5.22 \\
\hline F7 & 27.5 & 0.480 & 0.530 & 9.832 & 5.34 \\
\hline F8 & 30.3 & 0.520 & 0.480 & 8.463 & 5.43 \\
\hline & & & & & \\
\hline
\end{tabular}




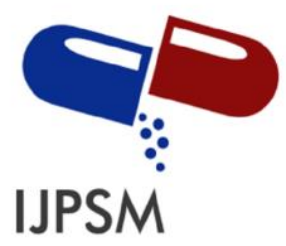

Saxena Kiran et al, International Journal of Pharmaceutical Sciences and Medicine (IJPSM), Vol.7 Issue. 1, January- 2022, pg. 81-93

\subsubsection{Physico-Chemical Characterization of levofloxacin effervescent floating Tablets}

Table no. 8 Physico-Chemical Characterization of levofloxacin effervescent floating Tablets

\begin{tabular}{|c|c|c|c|c|}
\hline $\begin{array}{c}\text { Formulation } \\
\text { Code }\end{array}$ & $\begin{array}{c}\text { Thickness } \\
(\mathbf{m m})^{*}\end{array}$ & $\begin{array}{c}\text { Hardness } \\
\left(\mathbf{k g} / \mathbf{c m}^{2}\right)^{*}\end{array}$ & $\begin{array}{c}\text { Friability } \\
(\%)\end{array}$ & $\begin{array}{c}\text { Weight } \\
\text { variation } \\
(\mathbf{m g})\end{array}$ \\
\hline F1 & 4.42 & 6.31 & 0.680 & 378.15 \\
\hline F2 & 4.32 & 6.56 & 0.509 & 387.25 \\
\hline F3 & 4.41 & 6.79 & 0.427 & 397.65 \\
\hline F4 & 4.32 & 6.48 & 0.567 & 396.05 \\
\hline F5 & 4.54 & 6.52 & 0.515 & 394.05 \\
\hline F6 & 4.25 & 6.78 & 0.669 & 395.75 \\
\hline F7 & 4.38 & 6.85 & 0.682 & 391.5 \\
\hline F8 & & 6.81 & 0.670 & 392.3 \\
\hline
\end{tabular}

\subsubsection{Drug Content:}

The drug content of all the formulation were found to be in the range of 95.2 to 99.2 , Which is within the specified limit as per Indian Pharmacopoeia 1996 (i.e. 90-110\% w/w). The results are shown in the table no.9. 


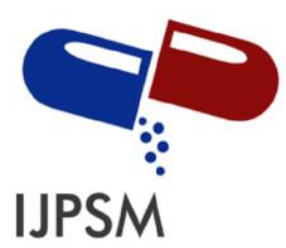

Saxena Kiran et al, International Journal of Pharmaceutical Sciences and Medicine (IJPSM), Vol.7 Issue. 1, January- 2022, pg. 81-93

Table no.9 Drug content of various formulations.

\begin{tabular}{|c|c|c|}
\hline S.NO & Formulation Code & \% Drug content \\
\hline 1. & F1 & $92 \%$ \\
\hline 2. & F2 & $90 \%$ \\
\hline 3. & F3 & $94 \%$ \\
\hline 4. & F4 & $94 \%$ \\
\hline 5. & F5 & $96 \%$ \\
\hline 6. & F6 & $92 \%$ \\
\hline
\end{tabular}

\subsubsection{Buoyancy lag time (BLT) and total floating time (TFT)}

Effervescent floating tablet of different formulations were noted, where F1 BLT of $28 \mathrm{sec}$ and TFT of $>12$ hours, F2 BLT of $30 \mathrm{sec}$ and TFT of $>10$ hours, BLT of $32 \mathrm{sec}$ and TFT of $>11$ hours, F4 BLT of $25 \mathrm{sec}$ and TFT of $>12$ hours, F5 BLT of $45 \mathrm{sec}$ and TFT of $>13$ hours, F6 BLT of $52 \mathrm{sec}$ and TFT of $>12$ hours, F7 BLT of $65 \mathrm{sec}$ and TFT of $>11$ hours, F8 BLT of $78 \mathrm{sec}$ and TFT of $>12$ hours, With reference to buoyancy studies results it can be concluded that the batch containing limonia acidissima showed good buoyancy lag time (BLT) and total floating time (TFT). Formulation F1 and F8 containing xanthan gum showed good BLT of 28 and $78 \mathrm{sec}$ and TFT of more than $12 \mathrm{hrs}$. The results are shown in table no 10

Table no. 10 Buoyancy lag time (BLT) and total floating time (TFT)

\begin{tabular}{|c|c|c|}
\hline Formulation Code & $\begin{array}{c}\text { Buoyancy lag times } \\
\text { (sec) }\end{array}$ & $\begin{array}{c}\text { Total Floating Time } \\
\text { (hrs) }\end{array}$ \\
\hline F1 & $28 \mathrm{sec}$ & $>12$ \\
\hline F2 & $30 \mathrm{sec}$ & $>10$ \\
\hline F3 & $32 \mathrm{ec}$ & $>12$ \\
\hline F4 & $25 \mathrm{sec}$ & $>13$ \\
\hline F5 & $45 \mathrm{sec}$ & $>11$ \\
\hline
\end{tabular}




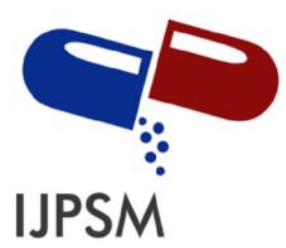

Saxena Kiran et al, International Journal of Pharmaceutical Sciences and Medicine (IJPSM), Vol.7 Issue. 1, January- 2022, pg. 81-93

ISSN: 2519-9889

Impact Factor: 5.721

\begin{tabular}{|c|c|c|}
\hline F6 & $52 \mathrm{sec}$ & $>12$ \\
\hline F7 & $65 \mathrm{sec}$ & $>11$ \\
\hline F8 & $78 \mathrm{sec}$ & $>12$ \\
\hline
\end{tabular}

\subsubsection{In vitro dissolution studies:}

Floating tablet showed sustained release of the drug in acidic condition $(\mathrm{pH}$ 1.2) and the drug release was found to be approximately linear. Approximately $8.71 \%$ of the drug was released initially. Furthermore, drug release from the floating tablet was controlled by the polymer. As the polymer content was increased and the drug loading was decreased, the release of drug was decreased significantly. In order to increase the release rate of drug, the ratio of polymer was decreased and plasticizer was increased. The combination polymer of final formulation F6, F7 \& F8showed best appropriate balance between buoyancy and drug release rate. Results of cumulative \% release have been shown in tubular and graphical form. It was found cumulative percentage of drug release decreases with increase in limonia gum concentration.

The drug released from formulation F1 to F4 was found to be 93.2, 93.3, 94.2 and $90.1 \%$ for levofloxacin respectively. The drug released from formulation F5 to F8 was found to be 89.3, 88.1, 90.1 and $95.1 \%$ for levofloxacin respectively.

The release rate of F8 was found to be higher when compared to other formulations this is due to increase in the concentration of limonia acidissima.

These results are indicating that has higher drug retarding ability for long duration. The results are shown in the table 11. 


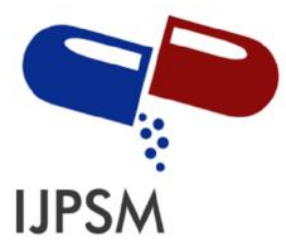

Saxena Kiran et al, International Journal of Pharmaceutical Sciences and Medicine (IJPSM), Vol.7 Issue. 1, January- 2022, pg. 81-93

ISSN: 2519-9889

Impact Factor: 5.721

Table 11 In- Vitro dissolution rate:

\begin{tabular}{|c|c|c|c|c|c|c|c|c|c|}
\hline S.No & Time(h) & F1 & F2 & F3 & F4 & F5 & F6 & F7 & F8 \\
\hline 1 & 1 & 8.71 & 8.95 & 9.22 & 9.16 & 9.30 & 8.69 & 9.20 & 9.36 \\
\hline 2 & 2 & 17.2 & 29.5 & 22.0 & 29.4 & 28.6 & 28.7 & 28.5 & 29.4 \\
\hline 3 & 4 & 39.7 & 35.5 & 38.6 & 38.4 & 43.5 & 35.5 & 36.4 & 39.4 \\
\hline 4 & 8 & 55.7 & 56.2 & 46.2 & 49.5 & 52.2 & 47.0 & 49.5 & 53.5 \\
\hline 5 & 10 & 74.5 & 73.4 & 68.5 & 66.9 & 65.1 & 68.2 & 69.9 & 69.9 \\
\hline 6 & 12 & 90 & 88 & 83.3 & 80.4 & 83.6 & 79.6 & 83.4 & 84.4 \\
\hline 7 & 14 & 93.2 & 93.3 & 94.2 & 90.1 & 89.3 & 88.1 & 90.1 & 95.1 \\
\hline
\end{tabular}

\subsubsection{Stability Study:}

After storage the formulation was analyzed for various physical parameters, results are showed in Table 12.

Table 12 : Stability study of best formulation F8

\begin{tabular}{|c|l|l|l|l|}
\hline Characteristic & Initial & $\mathbf{1}^{\text {st }}$ Month & $\mathbf{2}^{\text {nd }}$ Moth & $\mathbf{3}^{\text {rd }}$ Month \\
\hline Hardness $\left(\mathbf{k g} / \mathbf{c m}^{2}\right)^{*}$ & $6.85 \pm 0.03$ & $6.82 \pm 0.26$ & $6.80 \pm 0.28$ & $6.77 \pm 0.29$ \\
\hline Drug content $(\boldsymbol{\%})^{*}$ & $99.5 \pm 0.63$ & $99.4 \pm 0.79$ & $99.3 \pm 0.63$ & $98.2 \pm 0.58$ \\
\hline $\begin{array}{c}\text { In vitro drug release at } \\
\mathbf{1 4}^{\text {th }} \text { hour* }\end{array}$ & $95.1 \pm 0.65$ & $95.0 \pm 0.56$ & $94.8 \pm 0.59$ & $94.9 \pm 0.57$ \\
\hline $\begin{array}{c}\text { Appearance } \\
\text { Yellow- } \\
\text { White }\end{array}$ & No change & No change & No change \\
\hline
\end{tabular}




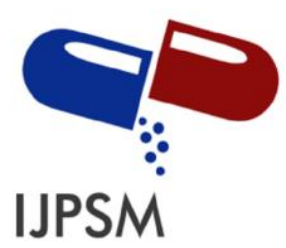

Saxena Kiran et al, International Journal of Pharmaceutical Sciences and Medicine (IJPSM), Vol.7 Issue. 1, January- 2022, pg. 81-93

ISSN: 2519-9889

Impact Factor: 5.721

\section{CONCLUSION}

The floating tablets were prepared by direct compression technique It may be concluded from the present study that slow and sustained release of levofloxacin over a period of $14 \mathrm{hr}$ was obtained (F1 to F8) by the using Limonia gum was successful in the formulation of floating tablet and at the same time it is effective in retarding the drug release. The cumulative percentage of drug release was decreased by increase in Limonia gum concentration.

In present studies, formulation containing limonia acidissima and xanthan is probably showing release up to $95.1 \%$ within $14 \mathrm{hrs}$.

According to stability study, it was found that there was no significant change in hardness, Drug content and dissolution rate of formulation F8 was $99 \%$ and $95.1 \%$.

\section{ACKNOWLEDGEMENT}

The author is thankful to the management of Swami Vivekanand College of Pharmacy, Indore. For providing necessary facilities to carry out the research work and heartily thankful to my guide and my Co-Guide for providing all the support and encouragement to carry out this studies.

\section{REFERENCES}

[1]. Alexander Streubel. Drug Delivery to the upper small intestine window using Gastroretentive technologies. Current option in pharmacology, 2006; 6, $501-508$.

[2]. Moes AJ. Gastroretentive dosage forms. Crit. Reviews in Ther. Drug carrier system, 1993; 10, 2, 149-195.

[3]. Sanjay Garg and Shring Sharma. Drug Delivery Oral. Business Briefing Pharmatech, 2003.

[4]. Jain NK. Advance in Controlled and Novel drug delivery. CBS publisher and distributor, New Delhi, 76-95.

[5]. Michel Afargan, Ph.D, VP Clinical Development, Intec Pharma, Noa Lapidot, Ph.D, VP Research \& Development, Intec Pharma Ltd. Controlled Release - Gastric Retention. Drug Delivery, 2005.

[6]. Davis SS. Formulation strategies for absorption windows. Drug Discovery Today, 2005; 10, 249-256.

[7]. Washington N, Washington C, Wilson CG. Physiological Pharmaceutics-II. Taylor and Francis, New York, 2001.

[8]. Klausner A, Eyal S, Lavy E, Friedman M, Hoffman A. Novel levodopa gastroretentive dosage form: in-vivo evaluation in dogs. J. Control. Release, 2003; 88, 117-126. 


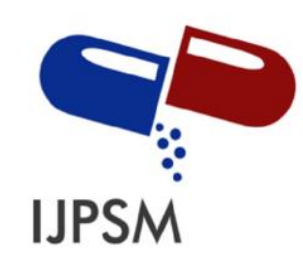

Saxena Kiran et al, International Journal of Pharmaceutical Sciences and Medicine (IJPSM), Vol.7 Issue. 1, January- 2022, pg. 81-93

ISSN: 2519-9889

Impact Factor: 5.721

[9]. O'Reilly S, Wilson C, Hardy J. The influence of food on the gastric emptying of multiparticulate dosage forms. Int. J. Pharm, 1987; 34, 213-216.

[10]. Sangekar S, VadinoW A, Chaudry I, Parr A, Beihn R, Digenis G. Evaluation of the effect of food and specific gravity of tablets on gastric retention time. Int. J. Pharm. 1987; 35, 187-197.

[11]. (Lieberman H.A. and Lachman L., 1999; Ansel H.C., 2009)

[12]. Sharma Aditya, Chauhan Vishakha, Nizami Tahir, Malviya Neelesh, Rathore Namrata, Vyas Isha Formulation and Evaluation of Floating Tablet of Tropisetron Journal of Drug Delivery and Therapeutics . 2019; 9(2-A):44-46.

[13]. Khan Mohd. Faarooq, Sharma Vimukhta .Dr and Atneriy Umesh, formulation and evaluation of floating effervescent tablet of Vol 8, Issue 5, 2019.

[14]. Yashpal Singh Chauhan*, Udichi Kataria, Ashok Dashora formulation and evaluation of floating tablet for indomethacin Journal of Drug Delivery and Therapeutics, 2018; 8(4):338-345.

[15]. Malviya Hema, Banweer Jitendra, Tahilani Praveen; The formulation of floating tablet CMC and albendazole used as matrix forming agent ; August 2018 Vol.:13, Issue:1.

[16]. Rawat Swati, Sangali Shradha, Gupta Akhilesh; Pharmaceutical Dosage Forms and Technology. 10(1): January- March, 2018.

[17]. Saddam C Shaikh*, Dnyaneshwar Sanap, Dipak V Bhusari, Shirish Jain, Pooja P Kochar, Vikram N Sanchati, formulation and evaluation of ibuprofen gastro-retentive Universal Journal of Pharmaceutical Research Volume 3, Issue 4, 2018.

[18]. Swapna Neela*. Jyothirmayee Avirneni., Likhitha Samineni., Vinay Kumar Durisetty and Krishna Mohan Chinnala, formulation, evaluation and optimization of etodolac floating tablets International Journal of Recent Scientific Research Vol. 8, Issue, 7, pp. 18880-18885, July, 2017.

[19]. Tekade.W Bharat, Jadhao .T Umesh, Bari . H Pankaj, Chaudhary. G Dipali. Vijay. Patil, formulation and evaluation of pantoprazole floating tablet by using natural gum R. J. Pharm. Sci. Innov. 2017; 6(4).

[20]. Nidhi Jain and Rahul Gupta, An Approach of Developing Floating Tablet of Lisinopril Current Research in Pharmaceutical Sciences 2016; 06 (04): 86-92

[21]. Parveen Rehana, Singh Pal Ajay, Bhargav Kumar Ranjeet, Verma Abhay, Shrivastav Priyanka; gastroretentative system for sustained release of metformin ; Vol 5, Issue 7, 2016

[22]. Ansari Mehboob Raza Afaque, Patil Yashwantrao Ravikant, Khandade Jaychand Vijaykumar, Yewale Nilkanth Pratik, Design and evaluation of gestroretentive floating drug delivery system of itopride hydrochloride Vol 4, Issue 07, 2015.

[23]. Asija Rajesh, Asija Sangeeta, Bhatt Shailendra, Sharma Deepak, Shah Avinash, and Sharma Priyanka; Formulation and evaluation of floating tablet of Valsartan Journal of Chemical and Pharmaceutical Research, 2015, 7(2):708-715 .

[24]. Singh Prabhjot, Srivastav Neha, kapoor Amit ; to formulate and evaluate gastro retentive floating tablets of cefixime trihydrate ; Vol 4, Issue 08, 2015. 